Archived version from NCDOCKS Institutional Repository http://libres.uncg.edu/ir/asu/

\title{
Appalachỉan
}

B O O N E, N O R T H C A R O L I N A

\section{Managing Risk In A Poor Economy: The Association Between Economic Activity And Auditor Response To Risk}

\author{
By: Penelope Bagley, Jack W. Dorminey, Dwayne McSwain, \& Tracy Reed
}

\begin{abstract}
We examine the association between economic climate and auditor risk acceptance as measured by the auditors' reaction to internal control weaknesses. We hypothesize and find that auditors address risk in a way that is conditioned on the economic environment. In particular, we find that during periods of weak economic activity, auditors tend to assess lower risk premiums and are less likely to resign in response to an adverse ICFR opinion. However, we find evidence that economic factors do not influence fees assessed by incoming auditors following a resignation in the presence of an ICFR weakness. Our results indicate that auditors modify their engagement risk strategies during challenging economic times and accept higher levels of risk to attract and retain clients. For the riskiest clients, however, economic factors do not appear to influence auditors' risk pricing.
\end{abstract}

Bagley, P., Dorminey, J., McSwain, D., Reed, T. (2016). Managing risk in a poor economy: The association between economic activity and auditor response to risk. Advances in Accounting, Vol. 32, pages 1-9. https://doi.org/10.1016/ j.adiac.2015.05.001. Publisher version of record available at: https://www.sciencedirect.com/science/article/pii/ S0882611015000292 


\title{
Managing risk in a poor economy:The association between economic activity and auditor response to risk
}

\author{
Penelope Bagley ${ }^{\mathrm{a}, 1}$, Jack W. Dorminey ${ }^{\mathrm{b},}$, Dwayne McSwain ${ }^{\mathrm{c}, 2}$, Tracy Reed ${ }^{\mathrm{a}, 3}$ \\ ${ }^{a}$ Appalachian State University, Walker College of Business, Department of Accounting, Boone, NC 28608, United States \\ ${ }^{\mathrm{b}}$ West Virginia University, College of Business and Economics, Department of Accounting, Morgantown, WV 26506, United States \\ ${ }^{c}$ Sam Houston State University, College of Business Administration, Department of Accounting, Huntsville, TX 77341, United States
}

\section{a r t i c le i n fo}

Available online 29 May 2015

Keywords:

Auditor fees

Auditor resignation

Economy

Internal control

Risk management

\section{$\mathrm{a} b \mathrm{~s} \mathrm{t} r \mathrm{a} \mathrm{c} t$}

We examine the association between economic climate and auditor risk acceptance as measured by the auditors' reaction to internal control weaknesses. We hypothesize and find that auditors address risk in a way that is conditioned on the economic environment. In particular, we find that during periods of weak economic activity, auditors tend to assess lower risk premiums and are less likely to resign in response to an adverse ICFR opinion. However, we find evidence that economic factors do not influence fees assessed by incoming auditors following a resignation in the presence of an ICFR weakness. Our results indicate that auditors modify their engagement risk strategies during challenging economic times and accept higher levels of risk to attract and retain clients. For the riskiest clients, however, economic factors do not appear to influence auditors' risk pricing.

\section{Introduction}

Subsequent to the passage of the Sarbanes-Oxley (SOX) Act (U.S. House of Representatives, 2002) and the continuing developments guided by the Public Company Accounting Oversight Board (PCAOB), the issue of engagement risk continues to be a major concern for the audit profession. Audit partners must give careful consideration to the selection and retention of clients while maintaining a balance with regard to the audit risks each client represents. Pre-SOX studies show that auditors react to engagement risk, as auditor resignations are more likely to occur when companies indicate signs of being high-risk clients (e.g., Bockus \& Gigler, 1998; Krishnan \& Krishnan, 1997; Shu, 2000). Post-SOX studies reiterate that auditors are less likely to continue with high-risk clients (e.g., Elder, Zhang, Zhou, \& Zhou, 2009; Landsman, Nelson, \& Rountree, 2009). Resignations, however, result in a loss of revenues to the firm. Audit firms are for-profit enterprises and must also make client engagement and continuance decisions based on their need for income and the economic environment in which they compete. Weak economic conditions have placed financial pressures on audit firms, forcing them to consider cost-cutting options such as lay-offs and spending cuts (Ramos, 2009). The increased financial pressure

\footnotetext{
ts Data availability: Data used in this paper are derived from publicly available sources.

* Corresponding author. Tel.: +1 3042937845.

E-mail addresses: bagleypl@appstate.edu (P. Bagley), jack.dorminey@mail.wvu.edu

(J.W. Dorminey), mcswain@shsu.edu (D. McSwain), reedtn@appstate.edu (T. Reed).

${ }^{1}$ Tel.: +1 8282626209

Tel.: +1 9362941284

${ }^{3}$ Tel. : +1 8282626125
}

may also cause audit firms to alter how they manage their clientbased revenue stream; for example, they may be less likely to resign from engagements when there is a high need for the income generated by the engagement. The purpose of this paper is to examine whether poor economic conditions change auditors' risk management policies, particularly the auditors' willingness to retain and properly price risky clients.

We examine the association between auditor resignations and the presence of a material weakness in internal control, as indicated by an adverse opinion on internal controls over financial reporting (ICFR), and what impact the recent economic recession has had on such resignations in an effort to gain insight into how economic conditions impact a firm's risk management. An increase in auditor resignations following an adverse ICFR opinion is consistent with an auditor reacting to a perceived increase in engagement risk associated with the opinion (Ashbaugh-Skaife, Collins, \& Kinney, 2007). However, difficult economic times may alter the profit-risk tradeoff, making a marginal increase in risk preferable to a resignation. An alternative reaction to the perceived increase in risk associated with an adverse ICFR opinion is to charge clients a risk premium (Canada, Sutton, \& Kuhn, 2009; Hogan \& Wilkins, 2008; Hoitash, Hoitash, \& Bedard, 2008; Pratt \& Stice, 1994; Raghunandan \& Rama, 2006). In a difficult economic climate, however, the fear of losing a client may result in an auditor's unwillingness or inability to fully price the risk associated with that particular client. Accordingly, we further investigate auditor fees following an adverse ICFR opinion. We also provide insight into whether economic factors influence subsequent auditors risk pricing for what we assume are the riskiest clients, those with an adverse ICFR opinion whose auditors have resigned. 
We use a sample of ICFR filers from November 15, 2004, through January 5, 2012, to investigate the association between adverse ICFR opinions and auditor resignations and fees in varying economic environments. We use the Leading Index for the United States provided by the Federal Reserve Bank of Philadelphia to measure the economic environment. We find evidence that audit firms are willing to accept more risk when the economy is poor. In particular, audit firms are more likely to continue with risky clients than they would be in more prosperous times. Although they continue to charge a risk premium to high-risk clients, as represented by those with an adverse ICFR opinion, the risk premium is significantly lower when the economy is weak. Given that prior literature shows a link between increased auditor fees and likelihood of auditor dismissal (Ettredge, Li, \& Scholz, 2007), the observed decrease in risk premiums may represent an effort by firms to lower the likelihood of their dismissal. However, for those clients considered the most risky (i.e., auditor resignations following adverse ICFR opinions during a recession), the economic state does not appear to impact the risk premium successor auditors charge. Thus, audit firms appear to alter their risk management policies and accept more risk when the economy is weak. However, when considering risk pricing for the riskiest of clients, the economic environment is not a factor.

Our paper extends both the accounting risk management literature and the literature that examines the influence of economic factors on the audit. Prior risk management literature has examined how audit firms use resignations and fees to manage engagement risk (e.g., Bockus \& Gigler, 1998; Johnstone \& Bedard, 2004; Krishnan \& Krishnan, 1997; Lee, Mande, \& Ortman, 2004; Munsif, Raghunandan, Rama, \& Singhvi, 2011; Pratt \& Stice, 1994; Shu, 2000). We extend the literature by examining how the use of these risk management tools is altered by the economic climate. Our paper also contributes to the limited research examining the impact of economic factors on the audit. Prior literature investigates changes in audit fees and audit quality during various economic climates (e.g., Ettredge, Fuerherm, \& Li, 2014; Krishnan \& Zhang, 2014; Leone, Rice, Weber, \& Willenborg, 2013). Most similar to our study, Schroeder and Hogan (2013) examine changes in client portfolios across varying economic climates and regulatory changes (i.e., Audit Standard 2 versus Audit Standard 5). While Schroeder and Hogan (2013) examine changes in financial, audit, and auditor risk of client portfolios as a whole, we extend their research by focusing on a subset of risky clients, those with adverse ICFR opinions, and how audit firms manage risk related to those particular clients over the various economic climates.

Our paper provides important insights to both practitioners and policy makers regarding risk management practices. Quality control standards at both the PCAOB and American Institute of Certified Public Accountants (AICPA) require firms to have policies and procedures in place to re-evaluate whether to continue client relationships each year, including examining various risk factors associated with client continuance (AICPA, 2011; PCAOB, 2003). Our results indicate that the economic environment impacts fee premium and retention decisions related to risky clients. Thus, our results demonstrate that practitioners are flexible with risk thresholds, indicating that firms' policies and procedures on quality control allow for variability in fee and retention decisions. Regulators and practitioners alike should keep in mind this need for flexibility when creating new policies and regulations in this area. Further, we provide insight into mechanisms other than cost-cutting that auditors use to manage their budget in difficult times. In particular, we provide evidence that auditors change how they manage their client base and risk profile, possibly in an effort to retain revenues.

Lastly, coupled with the findings of Ettredge et al. (2014), our findings provide insight regarding audit quality for high risk clients during difficult economic times. Ettredge et al. (2014) find that fee pressure during the economic downturn is associated with reduced audit quality. While we do not investigate the origins of the observed reduced fee premiums assessed to high risk clients during poor economic times (i.e., client pressure or auditor motivated), a reduction in fees as a result of client pressure may be associated with reduced audit quality for riskier clients, the exact clients in which higher quality audits are critical.

The remainder of this paper is organized into four sections. Section 2 discusses the background literature and develops the hypotheses. Section 3 describes the methodology and sample selection procedures used to investigate our research question. Results are presented in Section 4. Section 5 summarizes and concludes the paper.

\section{Background and hypotheses}

Auditor departures, whether initiated by the client or the auditor, occur for a variety of reasons. Extant research has shown client characteristics, such as size, leverage, management changes, and audit committee composition can result in an auditor change (Carcello \& Neal, 2003; DeFond, 1992; Ettredge et al., 2007; Johnson \& Lys, 1990; Krishnan, 1994). Audit firm departures can also be motivated by disagreements over audit fees or a mismatch between services requested and those able to be performed by audit firms (Ettredge et al., 2007; Turner, Williams, \& Weirich, 2005). Still other factors, such as the presence of internal control deficiencies (ICD), are associated with auditor changes (Ashbaugh-Skaife et al., 2007; Elder et al., 2009; Ettredge et al., 2007; Krishnan \& Visvanathan, 2007; Thevenot \& Hall, 2011).

\subsection{Internal controls and auditor changes}

Several recent research studies reveal a link between ICDs and auditor changes. Krishnan and Visvanathan (2007) directly test whether auditor changes are higher for firms that report ICDs versus those that do not report deficiencies. Findings support their hypotheses that firms reporting ICDs have more auditor changes than those without deficiencies. Thevenot and Hall (2011) find that entity level ICDs in particular, which are arguably more severe than account specific deficiencies, impact auditor changes. Ashbaugh-Skaife et al. (2007) examine auditor changes further and find that both auditor resignations and auditor dismissals are associated with higher frequencies of ICDs. Ettredge, Heintz, Li, and Scholz (2011) further Ashbaugh-Skaife et al. (2007) and find that firms receiving an adverse ICFR opinion are positively associated with auditor dismissals in particular. Auditor dismissals following the disclosure of ICDs and/or adverse ICFR opinions may occur for many reasons: to find a more compliant auditor, to punish the auditor for non-performance when the ICD is found by management versus the auditor, or, relatedly, to signal users of management efforts to improve overall financial reporting quality (Ashbaugh-Skaife et al., 2007; Ettredge et al., 2011). In contrast to Ettredge et al. (2011), Elder et al. (2009) examine the relationship between auditor resignations and ICDs. Using data from the year immediately following SOX implementation, they find that auditor resignations are more likely for firms with ICDs than for those without. Elder et al. (2009) conclude that the resignations are an effort made by the auditor to control litigation risk.

\subsection{Auditor resignations and litigation risk}

Auditor resignations motivated by an increase in litigation risk is a common finding among academic research (Bockus \& Gigler, 1998; Johnstone \& Bedard, 2004; Krishnan \& Krishnan, 1997; Lee et al., 2004; Shu, 2000). Auditor resignations are more likely to occur when a company has high financial distress, high variability in stock returns, low auditor independence, and the receipt of a modified opinion, particularly a going concern opinion (Krishnan \& Krishnan, 1997; Lee et al., 2004). Auditor resignations are also more likely following a restatement, especially one that is attributable to fraud or reverses a previously reported income, when there is a client disagreement, or when there are reportable events within the company (Huang \& Scholz, 2012; Krishnan \& Krishnan, 1997). All of these factors most likely increase the litigation risk for the auditor. 
Companies reporting ICDs often have many of the same characteristics that are associated with an increase in litigation risk for the auditor. Doyle, Ge, and McVay (2007) find firms disclosing material weaknesses are smaller, younger, financially weaker, more complex, growing rapidly, or are undergoing restructuring. Similarly, Ashbaugh-Skaife et al. (2007) find companies with ICDs have more complex operations, recent organizational changes, and more accounting risk than firms that do not have ICDs. Ashbaugh-Skaife et al. (2007) also note there are more auditor resignations for companies reporting ICDs than those not reporting ICDs. Similarly, other research finds that firms are more likely to dismiss clients when their internal control effectiveness is weak and that, as the number of weaknesses increase, the likelihood that the auditor will resign also increases (Johnstone \& Bedard, 2004; Thevenot \& Hall, 2011). These findings are consistent with Elder et al.'s (2009) conclusion that auditors resign from clients reporting ICDs in an attempt to manage litigation risk.

\subsection{Impact of economy on auditor resignations}

In the immediate years following the Enron debacle and the implosion of Arthur Anderson, audit firms became more selective regarding their client base and began to resign from riskier clients (Hindo, 2003; Landsman et al., 2009). These resignations from risky clients were not, however, due entirely to audit firms becoming more risk averse. At that time, audit firms were faced with substantially more work. The demise of Arthur Anderson meant that many large companies were in the market for a new auditor. Furthermore, the requirement that public companies obtain an internal control audit, outlined in Section 404 of SOX, substantially increased the workload of larger auditing firms (Landsman et al., 2009). This prospect of new clients, coupled with the increased workload associated with public clients, allowed audit firms the opportunity to resign from riskier clients without an unnecessary financial burden. ${ }^{4}$

Unfortunately, poor economic conditions may not afford accounting firms the opportunity to resign from riskier clients as frequently as they might during more prosperous times. Accounting firms have lost audit clients due to bankruptcy, and some clients have chosen to forego an annual audit. Further, firms have lost consulting engagements due to clients' own cost-cutting strategies. Accounting firms themselves have been forced to consider cost-cutting options such as lay-offs and spending cuts (Ramos, 2009). Therefore, we may see that auditor resignations of clients with increased risk factors, such as those receiving an adverse opinion on ICFR, decreases during an economic downturn.

In contrast, an economic downturn likely impacts the operations and financial reporting of many audit firms' clients in a negative way. Such impacts can significantly increase previously identified audit risks or cause new risks to arise (PCAOB, 2008). The concern over increased audit risk during the most recent economic downturn was large enough to warrant attention from standard setters at both the PCAOB and the International Auditing and Assurance Standards Board (IAASB), as both organizations issued special practice alerts related to the increase in risk (IAASB, 2009; PCAOB, 2008). This response to the increase in risk by standard setters, coupled with the increase in overall risk factors among clients, suggests we may observe an increase in resignations of riskier clients during an economic downturn. Despite this possibility, retaining clients during difficult economic times is necessary for a firm's long-term viability. We assert that long-term viability concerns during a weak economy will cause firms to retain clients that would otherwise be dropped, with the expectation that internal control weaknesses can be remedied. As all audit firms seek to retain a client base during

\footnotetext{
${ }^{4}$ As Landsman et al. (2009) point out, an alternative explanation for the observed changes in auditor change behavior immediately following the demise of Arthur Anderson and the implementation of SOX could be due to the availability of former Anderson clients that were better aligned with the Big 4, thus allowing them to resign from less well aligned clients without the negative financial impact.
}

difficult economic times, a dropped client (and the associated revenue) is more difficult to replace during a downturn. Therefore we state our first hypothesis as follows:

H1. Auditors are less likely to resign following an adverse ICFR opinion when the economy is weak.

\subsection{Impact of economy on auditor fees}

An alternative way audit firms can mitigate risk is to increase the audit fees associated with risky clients. Generally, the presence of ICDs is associated with an increase in audit fees (Canada et al., 2009; Hogan \& Wilkins, 2008; Hoitash et al., 2008; Raghunandan \& Rama, 2006). Such fee premiums continue to exist in the years following an adverse ICFR opinion, regardless of whether the deficiency is remediated, indicating that the fee premium is not related simply to workload, but instead to auditors continuing to associate higher risk with these clients (Munsif et al., 2011).

As is the case for all business entities attempting to endure economic hardship, audit firms are forced to consider their own need for income when considering risky clients and audit fees. During difficult economic times, firms are faced with significantly more pressure from clients to decrease audit fees (Ettredge et al., 2014). Further, prior research finds that increased audit fees can lead to auditor dismissals (Ettredge et al., 2007). Audit firms may not be in an economic position to afford the loss of revenues associated with dismissals and may therefore choose to limit or even eliminate any fee increase assessed to clients with ICDs in an effort to retain the current and future income from those clients.

We contend that audit firms will continue to charge a risk premium to clients with adverse ICFR opinions, as prior literature suggests. However, we believe the magnitude of the premium will be lower when the economy is weak, in the interest of retaining clients. Therefore, we hypothesize the following:

H2. Risk premiums assessed on adverse ICFR opinions are lower when the economy is weak.

\subsection{Subsequent auditor fees}

Regardless of the change in the relationship between adverse ICFR opinions and auditor resignations during times of economic difficulty, accounting firms are still likely to resign from those clients with adverse ICFR opinions that represent the highest level of risk. It is therefore likely that a firm taking on such a client in a recessionary period is in the most need of building and retaining a client base. Because these clients are arguably the most risky and the recent economic downturn is particularly acute, we are interested in assessing the degree to which the influence of economic pressures may or may not exceed the pressure to price risk appropriately. In the case where risk pricing is dominated by economic influences, the risk premium assessed on internal control weaknesses during a poor economy will be comparatively lower, so much so that the economic influences in a post-resignation situation may, in fact, dominate. Alternatively, when considering the level of risk represented by those clients with adverse ICFR opinions whose auditors resigned, the need for appropriate risk pricing may dominate economic influences. Therefore we pose the following research question:

RQ1. Will the premium assessed by incoming audit firms following a resignation after an adverse ICFR opinion be impacted by the economy?

\section{Research methodology}

The models used to test our hypotheses are based on prior research, including models used by Ettredge et al. (2011) to test auditor dismissals, 


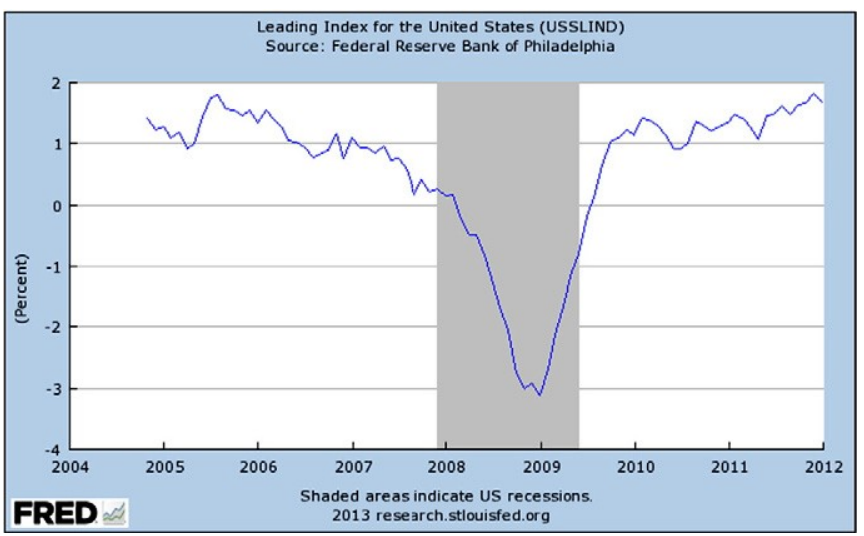

Fig. 1. Leading index for the United States from November 2004-January 2012

Krishnan and Krishnan (1997) to test litigation risk factor differences between resignations and dismissals, Lee et al. (2004) to compare board of director characteristic differences of firms with resignations versus dismissals, ${ }^{5}$ and Huang and Scholz (2012) to test the association between restatements and resignations. Appendix A lists and defines client and auditor engagement factors identified by prior studies as variables that affect auditor changes and audit fees. We include these factors as control variables in our models.

We use the following logistic regression model to test $\mathrm{H} 1$ that auditors are less likely to resign following an adverse ICFR opinion when the economy is weak:

\section{RES $1 / 4 \beta_{0} \mathrm{p} \beta_{1}$ ICWEAK $\mathrm{p} \beta_{2}$ ECON $\mathrm{p} \beta_{3}$ ECON * ICWEAK $\mathrm{p} \beta_{4} A S 5$ $\mathrm{p} \beta_{5} C S I Z E \mathrm{p} \beta_{6} B K M K \mathrm{p} \beta_{7} L E V \mathrm{p} \beta_{8} R O A \mathrm{p} \beta_{9} L O S S \mathrm{p} \beta_{10} S P E C$}

$$
\begin{aligned}
& \mathrm{p} \beta_{11} \text { CEO } \mathrm{p} \beta_{12} \text { GOCN } \mathrm{p} \beta_{13} \text { ABFEE } \mathrm{p} \beta_{14} \text { BIG } 4 \mathrm{p} \beta_{15} \text { RESTATE } \\
& \mathrm{p} \beta_{16} \text { DISAGREE } \mathrm{p} \beta_{17} \text { REPORTABLE } \mathrm{p} \beta_{18} \text { AINDEP } \mathrm{p} \beta_{19} \text { INDEP } \\
& \mathrm{p} \beta_{20} \text { ABRETANp } \varepsilon:
\end{aligned}
$$

The dependent variable, RES, is coded 1 if there is an auditor resignation during the fiscal year and is 0 otherwise; indicating that there was either no change in auditor or that the auditor change was the result of a dismissal. The independent variable, ICWEAK, is coded 1 if the incumbent auditor issues an adverse ICFR report and 0 otherwise. Our tests of the association between economic activity and auditor behavior require a relatively responsive, but non-volatile measure of near-term, forward-looking economic activity. The Leading Index for the United States provided by the Federal Reserve Bank of Philadelphia utilizes multiple economic inputs (e.g., housing permits, unemployment claims, manufacturing, and interest rates) to provide one composite index to capture economic trends. The combination of these metrics into a single index has a smoothing effect that avoids much of the volatility reflected in individual components, therefore providing us with a reliable, allencompassing measure of the economic environment. ${ }^{6}$ A higher index value reflects a healthier economic outlook. We use the Leading Index for the United States provided by the Federal Reserve Bank of Philadelphia as a measure of broad economic conditions and label this metric ECON. Fig. 1 presents a graph of the Leading Index over our sample period. Support for $\mathrm{H} 1$ is found when the coefficient on the interaction term ECON*ICWEAK is significant and positive. The remaining variables,

\footnotetext{
${ }^{5}$ Prior research assesses the independence of corporate leadership in two ways: (1) in dependence of the board of directors, and (2) independence of the audit committee. We include audit committee independence in our specification as it most appropriately relates to our characteristic of interest; auditor resignations.

${ }^{6}$ The Philadelphia Reserve Bank makes the Leading Index for the United States freely available via the FRED database provided by the St. Louis Federal Reserve Bank.
}

Table 1

Sample details.

\begin{tabular}{lcc}
\hline & Records & Registrants \\
\hline ICFR opinions from November 15, 2004 to January 5, 2012 & 30,403 & 5894 \\
Missing ICFR or financial data & $(2121)$ & $(348)$ \\
Sample in study & 28,282 & 5546 \\
\hline
\end{tabular}

defined in Appendix A, are control variables shown to influence auditor changes in prior research. The model is applied to the entire population of ICFR reports, with a total $n$ of 28,282 .

To test H2, that risk premiums following adverse ICFR opinions decrease when the economy is weak, and to provide insight into our research question (RQ1) regarding the influence of the economy on the risk premiums assessed by incoming auditors following resignations post adverse ICFR opinions, we use the following specification:

\section{InðFEE $1 / 4 \beta_{0} \mathrm{p} \beta_{1} I C W E A K \mathrm{p} \beta_{2} N U M W K \mathrm{p} \beta_{3} E C O N \mathrm{p} \beta_{4} E C O N$ * ICWEAK $\mathrm{p} \beta_{5} R E S \mathrm{p} \beta_{6} E C O N^{*} R E S \mathrm{p} \beta_{7} R E S^{*} I C W E A K$ $\mathrm{p} \beta_{8} E C O N^{*} I C W E A K^{\star} R E S \mathrm{p} \beta_{9} A S 5 \mathrm{p} \beta_{10} A S S E T$ $\mathrm{p} \beta_{11} S A L E=A S S E T \mathrm{p} \beta_{12} L E V \mathrm{p} \beta_{13} R O A \mathrm{p} \beta_{14} L O S S \mathrm{p} \beta_{15} D E L A Y$ $\mathrm{p} \beta_{16} A R E C \mathrm{p} \beta_{17} I N V \mathrm{p} \beta_{18} S P E C \mathrm{p} \beta_{19} R E S T A T E \mathrm{p} \beta_{20} L S E G$ $\mathrm{p} \beta_{21}$ RESTRUCT $\mathrm{p} \beta_{22}$ GOCN $\mathrm{p} \beta_{23}$ BKMK $\mathrm{p} \beta_{24} B I G 4 \mathrm{p} \varepsilon$ :

Consistent with Ettredge et al. (2011), we define the dependent variable, $\ln (F E E)$, as the natural log of audit fees for the year following the adverse ICFR opinion. The variables ICWEAK, ECON, and $E C O N^{*} I C W E A K$ are consistent with those used in Eq. (1). Support for $\mathrm{H} 2$ is found when the coefficient on the interaction term $E C O N^{*} I C W E A K$ is significant and positive. We also include an indicator for auditor resigna-

tions (RES) and additional interactions, including a three-way interaction of $E C O N^{*} I C W E A K^{*} R E S$. We examine the coefficient on the three-way interaction to provide insight into our research question. A significant coefficient on the three-way interaction term indicates that the economy is a factor in the risk premiums assessed by incoming auditors following resignations in the presence of an adverse ICFR opinion. The remaining model variables, previously defined in Appendix A, are control variables for other company characteristics identified by prior research as influencing audit fees. The model is applied to the entire population of ICFR reports, with a total $n$ of 28,282 .

\section{Results and analysis}

\subsection{Sample and descriptive statistics}

Table 1 presents details of our sample obtained from Audit Analytics. We extracted 30,403 records, representing 5894 distinct registrants with an ICFR report from November 15, 2004 to January 5, 2012. From this, we lost 2121 records representing 348 distinct registrants that were missing either ICFR data or information from Compustat needed to calculate control variables. Our final sample results in 28,282 records with ICFR reports representing 5546 distinct registrants. We also obtained a file from Audit Analytics containing all auditor changes. This file was merged with our final sample of ICFR reports, resulting in 1443 records of companies that changed auditors within one calendar year of the issuance of an ICFR report, of which 295 were indicated as resignations. We utilize our entire sample of 28,282 ICFR opinions to test $\mathrm{H} 1, \mathrm{H} 2$, and our research question. Table 2 presents descriptive statistics for our sample variables for the full sample, the resignation sample, and the non-resignation sample. ${ }^{7}$

\footnotetext{
${ }^{7}$ All scale variables are winsorized at the $1 \%$ level to address outliers.
} 
Table 2

Sample descriptive statistics.

\begin{tabular}{|c|c|c|c|c|c|c|c|c|c|c|c|c|}
\hline & \multicolumn{4}{|c|}{ FullSample $(\mathrm{n}=28,282)$} & \multicolumn{4}{|c|}{ Resignation $(\mathrm{n}=295)$} & \multicolumn{4}{|c|}{ Noresignation $(\mathrm{n}=27,987)$} \\
\hline & Min & Mean & $\operatorname{Max}$ & SD & Min & Mean & $\operatorname{Max}$ & SD & Min & Mean & Max & SD \\
\hline ABFEE & $(2.7506)$ & 0.0019 & 1.7726 & 0.7072 & $(2.7506)$ & $(0.0716)$ & 1.7736 & 0.8214 & $(2.7506)$ & 0.0027 & 1.7726 & 0.7059 \\
\hline ABRETAN & 0.0000 & 0.0010 & 0.1657 & 0.0024 & 0.0000 & 0.0011 & 0.0272 & 0.0028 & 0.0000 & 0.0010 & 0.1657 & 0.0024 \\
\hline AINDEP & 0.0000 & 0.9752 & 1.0000 & 0.1556 & 0.0000 & 0.9356 & 1.0000 & 0.2459 & 0.0000 & 0.9756 & 1.0000 & 0.1543 \\
\hline $\mathrm{AREC}^{1}$ & $(4.6502)$ & 4.6329 & 12.5633 & 2.7788 & $(4.6502)$ & 3.4562 & 10.0272 & 2.9051 & $(4.6502)$ & 4.6453 & 12.5633 & 2.7748 \\
\hline AS5 & 0.0000 & 0.6246 & 1.0000 & 0.4842 & 0.0000 & 0.4644 & 1.0000 & 0.4996 & 0.0000 & 0.6263 & 1.0000 & 0.4838 \\
\hline ASSET $^{1}$ & 1.9626 & 7.0322 & 13.4392 & 1.9752 & 1.9626 & 5.7133 & 12.1306 & 1.7827 & 1.9626 & 7.0461 & 13.4392 & 1.9724 \\
\hline BIG4 & 0.0000 & 0.8060 & 1.0000 & 0.3954 & 0.0000 & 0.4644 & 1.0000 & 0.4996 & 0.0000 & 0.8096 & 1.0000 & 0.3926 \\
\hline BKMK & (6.1479) & 0.3717 & 7.2074 & 0.9646 & (6.1479) & 0.5281 & 7.2074 & 1.0252 & (6.1479) & 0.3701 & 7.2074 & 0.9638 \\
\hline CEO & 0.0000 & 0.0343 & 1.0000 & 0.1819 & 0.0000 & 0.0101 & 1.0000 & 0.1005 & 0.0000 & 0.0345 & 1.0000 & 0.1826 \\
\hline CSIZE $^{1}$ & 0.0000 & 19.7427 & 25.4394 & 3.4302 & 0.0000 & 17.8328 & 25.2360 & 3.8265 & 0.0000 & 19.7629 & 25.4394 & 3.4202 \\
\hline DELAY & 28.0000 & 70.2383 & 325.0000 & 31.7445 & 28.0000 & 94.9966 & 325.0000 & 59.1831 & 28.0000 & 69.9774 & 325.0000 & 31.2251 \\
\hline DISAGREE & 0.0000 & 0.0002 & 1.0000 & 0.0133 & 0.0000 & 0.0034 & 1.0000 & 0.0582 & 0.0000 & 0.0001 & 1.0000 & 0.0120 \\
\hline ECON & $(2.9672)$ & (1.0260) & 0.2900 & 1.2964 & $(2.9672)$ & (0.8265) & 0.2900 & 1.3103 & $(2.9672)$ & (1.0282) & 0.2900 & 1.2959 \\
\hline GOCN & 0.0000 & 0.0234 & 1.0000 & 0.1513 & 0.0000 & 0.0983 & 1.0000 & 0.2982 & 0.0000 & 0.0227 & 1.0000 & 0.1488 \\
\hline ICWEAK & 0.0000 & 0.0843 & 1.0000 & 0.2778 & 0.0000 & 0.4610 & 1.0000 & 0.4993 & 0.0000 & 0.0803 & 1.0000 & 0.2718 \\
\hline INDEP & 0.0000 & 0.9375 & 0.9999 & 0.2209 & 0.0000 & 0.8417 & 1.0000 & 0.3155 & 0.0000 & 0.9385 & 1.0000 & 0.2195 \\
\hline $\mathrm{INV}^{1}$ & $(4.6502)$ & 1.6314 & 9.9200 & 4.3248 & $(4.6502)$ & 0.4830 & 8.5071 & 3.7420 & $(4.6502)$ & 1.6435 & 9.9200 & 4.3290 \\
\hline LEV & 0.0284 & 0.5661 & 1.7849 & 0.2908 & 0.0284 & 0.5741 & 1.7849 & 0.3673 & 0.0284 & 0.5660 & 1.7849 & 0.2899 \\
\hline LOSS & 0.0000 & 0.2755 & 1.0000 & 0.4468 & 0.0000 & 0.4542 & 1.0000 & 0.4987 & 0.0000 & 0.2737 & 1.0000 & 0.4458 \\
\hline LSEG & 1.0000 & 1.9638 & 36.0000 & 3.9553 & 1.0000 & 1.7288 & 30.0000 & 3.7016 & 1.0000 & 1.9663 & 36.0000 & 3.9579 \\
\hline NUMWK & 0.0000 & 0.1999 & 20.0000 & 0.9647 & 0.0000 & 1.4949 & 11.0000 & 2.3033 & 0.0000 & 0.1863 & 20.0000 & 0.9311 \\
\hline REPORTABLE & 0.0000 & 0.0175 & 1.0000 & 0.1311 & 0.0000 & 0.4610 & 1.0000 & 0.4993 & 0.0000 & 0.0128 & 1.0000 & 0.1125 \\
\hline RESTATE & 0.0000 & 0.1109 & 1.0000 & 0.3140 & 0.0000 & 0.1559 & 1.0000 & 0.3634 & 0.0000 & 0.1104 & 1.0000 & 0.3134 \\
\hline RESTRUCT & 0.0000 & 0.2683 & 1.0000 & 0.4431 & 0.0000 & 0.1898 & 1.0000 & 0.3928 & 0.0000 & 0.2692 & 1.0000 & 0.4435 \\
\hline ROA & (1.3860) & (0.0078) & 0.5245 & 0.2007 & $(1.3860)$ & $(0.0711)$ & 0.5245 & 0.3070 & (1.3860) & (0.0071) & 0.5245 & 0.1991 \\
\hline SALE/ASSET & 0.0000 & 0.7877 & 4.3421 & 0.7411 & 0.0000 & 0.6914 & 4.3421 & 0.7323 & 0.0000 & 0.7887 & 4.3421 & 0.7411 \\
\hline SPEC & 0.0000 & 0.1324 & 1.0000 & 0.3389 & 0.0000 & 0.2644 & 1.0000 & 0.4418 & 0.0000 & 0.1310 & 1.0000 & 0.3374 \\
\hline
\end{tabular}

These variables are computed as natural logs.

In Table 3 we present Pearson correlations for all variables. An analysis of the correlations provided in Table 3 reveal significant associations between resignations (RES) and most variables included in our study. Most importantly for our study, RES is positively associated with ECON and ICWEAK. The reported correlations are consistent with prior work. A summary of reported internal control weaknesses (ICWEAK) and the number of weaknesses reported (NUMWK) per sample year is presented in Table $4 .^{8}$

In an untabulated preliminary analysis, we validate our data set in terms of prior literature. Our validation consists of replicating the key findings in two empirical studies, Ashbaugh-Skaife et al. (2007) and Elder et al. (2009) upon which our study relies. In both cases we employ the same model and methodological approach as the published works. Consistent with Ashbaugh-Skaife et al. (2007), we find a positive association between changes in auditor (resignation or dismissal) and an adverse ICFR opinion for our sample firms. Consistent with Elder et al. (2009), we find that, in our sample, adverse ICFR opinions increase the likelihood of resignations. We demonstrate comparability and consistency with prior work, and therefore proceed with our analyses.

\subsection{Test of hypothesis 1}

To test $\mathrm{H} 1$, we examine the impact of the economy on the frequency of resignations following an adverse ICFR opinion. Table 5 presents the results from the logistical regression used to test $\mathrm{H} 1$. We report results

for a two-way, cluster-robust standard error estimation of Eq. (1). ${ }^{9}$ Our model is significant ( $p$ b 0.001) with a Chi-Square of 1007.63. We

\footnotetext{
${ }^{8}$ Our dataset encompasses registrants with an ICFR report from November 15, 2004 to January 5, 2012. The vast majority of audit reports for the 2011 year arrived subsequent to January 5, 2012. As a result, the number of observations for the 2011 sample year $(n=545)$ is smaller than for the other years.

9 The two-way, cluster-robust standard error estimation procedure is presented by Gow, Ormazabal, and Taylor (2010). This estimation procedures controls for heteroskedasticity in variance simultaneously for two vectors. We control for auditor and reporting year.
}

find that adverse ICFR reports, as measured by the ICWEAK variable, are a significant predictor for auditor resignations $(p=0.014)$. The economic environment variable $(E C O N)^{10}$ is significant and negative ( $p$ b 0.001), indicating that, in general, the more favorable the economy, the less likely the auditor is to resign from an engagement. ${ }^{11}$ The interaction variable between adverse ICFR reports and economic outlook $\left(E C O N^{*} I C W E A K\right)$ is significant $(p=0.003)$ and positive. The positive coefficient on the interaction term indicates that an audit firm has an incremental increase (decrease) in the tendency to resign in response to an adverse ICFR report when economic outlook is more favorable (unfavorable). That is, an auditor is less likely to resign from an audit engagement where an adverse ICFR opinion is issued when the economy is weak as compared to when it is strong. Thus, we find support for our firsthypothesis.

The significant negative coefficient on the AS5 control variable ( $p=$ 0.053 ) indicates, not surprisingly, that auditors are less likely to resign when performing the ICFR audit under the more simplified Audit Standard 5 guidance than when performing the audit under the guidance of the now superseded Audit Standard 2. Consistent with prior research (i.e., Carcello \& Neal, 2003; Johnson \& Lys, 1990), we also find that larger companies are less likely to experience an auditor resignation (CSIZE, $p=0.059) .{ }^{12}$ Companies that utilize Big 4 auditors $(B I G 4, p=0.001)$ are less likely to experience an auditor resignation, consistent with Johnson and Lys (1990) results. Auditors are more likely to resign

\footnotetext{
${ }^{10}$ In untabulated results we replicate our entire analysis using an alternative proxy for
} economic activity. We use industrial production, manufacturing inventory and gross domestic product in a factor analysis to create our own economic index metric. The results obtained with the alternative economic metric are qualitatively identical to those reported.

${ }^{11}$ We do not hypothesize or expect economic factors to impact overall resignations, and therefore leave future research to further explore the observed negative relationship between economy and resignations.

${ }^{12}$ In untabulated results we also estimate our modelusing thelog of total assets as a size control. The results are qualitatively identical yielding the same conclusion we formally present in Table 5 . 
Table 3

Pearson correlations.

\begin{tabular}{|c|c|c|c|c|c|c|c|c|c|c|c|}
\hline & ABFEE & ABRETAN & AINDEP & AREC & ASSET & AS5 & BIG4 & BKMK & CEO & DELAY & DISAGREE \\
\hline ABFEE & 1.0000 & & & & & & & & & & \\
\hline ABRETAN & $(0.0149) *$ & 1.0000 & & & & & & & & & \\
\hline AINDEP & $(0.0187)^{\star *}$ & $0.1001^{\star * *}$ & 1.0000 & & & & & & & & \\
\hline AREC & $0.0202^{* * *}$ & $(0.1060)^{* \star *}$ & $0.0391^{* * *}$ & 1.0000 & & & & & & & \\
\hline ASSET & $(0.0025)$ & $(0.0980)^{* * *}$ & $0.0552^{\star \star *}$ & $0.8010^{* * *}$ & 1.0000 & & & & & & \\
\hline AS5 & $(0.0093)$ & $0.3196^{\star \star *}$ & $(0.1227)^{\star \star *}$ & $0.0103^{*}$ & $0.0459^{* * *}$ & 1.0000 & & & & & \\
\hline BIG4 & $(0.0030)$ & $(0.0304)^{\star * *}$ & $0.0510^{* * *}$ & $0.1605^{* * *}$ & $0.3169^{* * *}$ & $(0.0343)^{* * *}$ & 1.0000 & & & & \\
\hline BKMK & $(0.1186)^{* \star \star}$ & $0.0833^{* * *}$ & $(0.0075)$ & $0.0449^{* * *}$ & $0.0372^{* * *}$ & $0.0749^{\star * *}$ & $(0.0779)^{\star \star \star}$ & 1.0000 & & & \\
\hline CEO & $0.0193^{\star \star}$ & $(0.0052)$ & $0.0101^{*}$ & $0.0664^{* * *}$ & $0.0851^{\star * \star}$ & 0.0007 & $0.0629^{\star \star *}$ & $(0.0159) * *$ & 1.0000 & & \\
\hline DELAY & 0.0091 & $0.0250^{* * *}$ & $(0.0177)^{* *}$ & $(0.0716)^{\star \star \star}$ & $(0.0837)^{\star \star \star}$ & $(0.0174)^{* *}$ & $(0.0402)^{\star \star \star}$ & $0.0305^{* * *}$ & $(0.0354)^{\star * *}$ & 1.0000 & \\
\hline DISAGREE & 0.0003 & $(0.0055)$ & 0.0021 & $(0.0083)$ & $(0.0115)^{*}$ & $(0.0172) * *$ & $(0.0069)$ & $(0.0010)$ & $(0.0025)$ & $0.0254^{\star * *}$ & 1.0000 \\
\hline $\mathrm{ECON}$ & $0.0108^{*}$ & $(0.2687)^{\star \star \star}$ & $0.2310^{\star * *}$ & $(0.0106) *$ & $(0.0434)^{\star \star \star *}$ & $(0.6232)^{* * *}$ & $0.0219^{\star * *}$ & $(0.0667)^{\star \star *}$ & $(0.0019)$ & $0.0182^{\star \star}$ & $0.0126^{*}$ \\
\hline GOCN & $(0.0024)$ & $0.0711^{* * *}$ & $(0.0864)^{\star * *}$ & $(0.1575)^{* * *}$ & $(0.1467)^{\star \star \star ~}$ & $0.0381^{\star \star *}$ & $(0.0670)^{\star \star \star}$ & $(0.0444)^{\star \star *}$ & $(0.0112)^{*}$ & $0.0928^{* * *}$ & $(0.0021)$ \\
\hline ICWEAK & 0.0004 & $(0.0098)^{*}$ & 0.0051 & $(0.0808)^{\star \star *}$ & $(0.1144)^{* \star \star}$ & $(0.1349)^{* * *}$ & $(0.0871)^{\star \star \star}$ & $(0.0262)^{\star \star *}$ & 0.0030 & $0.3073^{\star \star \star}$ & $0.0438^{* * *}$ \\
\hline INDEP & 0.0012 & $0.0847^{\star \star *}$ & $(0.0161)^{* *}$ & $0.0385^{* * *}$ & $0.0508^{* * *}$ & $(0.0399) * * *$ & $0.1599^{* * *}$ & $0.0149^{*}$ & $0.0202^{\star * *}$ & $(0.0805)^{* * *}$ & $(0.0004)$ \\
\hline INV & $0.0946^{\star * *}$ & $(0.0323)^{\star \star *}$ & $0.0283^{* * *}$ & $0.3840^{* * *}$ & $0.3862^{\star * *}$ & $0.0476^{\star * *}$ & $0.1596^{\star * *}$ & $0.0163^{* *}$ & $0.0620^{* * *}$ & $(0.0294)^{* * *}$ & 0.0004 \\
\hline LEV & $(0.0621)^{* * *}$ & $0.0329^{\star * *}$ & $(0.0266)^{\star \star *}$ & $0.3781^{* * *}$ & $0.3513^{\star \star \star}$ & 0.0070 & $(0.0116)^{*}$ & $(0.1469)^{\star \star \star}$ & $0.0117^{*}$ & $(0.0114)^{*}$ & 0.0033 \\
\hline LOSS & 0.0008 & $0.2652^{* * *}$ & $(0.0857)^{* * *}$ & $(0.3138)^{* * *}$ & $(0.2959)^{* \star *}$ & $0.1050^{* * *}$ & $(0.0805)^{* * *}$ & $(0.0136)^{*}$ & $(0.0100)^{*}$ & $0.1144^{\star * *}$ & 0.0037 \\
\hline LSEG & $(0.0009)$ & $0.0215^{\star * *}$ & 0.0043 & $0.1399^{* * *}$ & $0.1915^{\star * *}$ & $0.1058^{* \star *}$ & $0.0952^{* * *}$ & $(0.0174)^{* *}$ & $0.0270^{* * *}$ & $(0.0097)$ & $(0.0035)$ \\
\hline NUMWK & 0.0009 & $(0.0249)^{\star \star \star}$ & 0.0055 & $(0.0538)^{\star * *}$ & $(0.0788)^{* \star *}$ & $(0.1055)^{* * *}$ & $(0.0606)^{\star \star \star}$ & $(0.0281)^{\star * *}$ & 0.0005 & $0.3849^{\star \star *}$ & $0.0221^{* * *}$ \\
\hline REPORTABLE & $0.0244^{* * *}$ & 0.0071 & 0.0074 & $(0.0353)^{* * *}$ & $(0.0611)^{\star \star \star *}$ & $(0.0564) * * *$ & $(0.0191) * *$ & 0.0045 & 0.0015 & $0.1198^{* * *}$ & $0.0388^{* * *}$ \\
\hline RES & $(0.0107)^{*}$ & 0.0038 & $(0.0261)^{* * *}$ & $(0.0435)^{* * *}$ & $(0.0686)^{* \star *}$ & $(0.0340) * * *$ & $(0.0887)^{\star * \star}$ & $0.0166^{* *}$ & $(0.0136) *$ & $0.0801^{* * *}$ & $0.0248^{\star * \star}$ \\
\hline RESTATE & $(0.0005)$ & $(0.0064)$ & $0.0202^{\star \star *}$ & $(0.0134)^{*}$ & $(0.0327)^{\star \star *}$ & $(0.1041)^{* * *}$ & (0.0095) & $(0.0053)$ & 0.0009 & 0.0014 & $0.0122^{*}$ \\
\hline RESTRUCT & 0.0004 & $0.0198^{\star \star *}$ & $(0.0090)$ & $0.1215^{\star \star *}$ & $0.1151^{\star * *}$ & $0.0464^{\star * *}$ & $0.1555^{\star \star *}$ & $(0.1233)^{* * *}$ & $0.0768^{\star \star *}$ & $(0.0386)^{* * *}$ & $(0.0021)$ \\
\hline ROA & $(0.0100)^{*}$ & $(0.0394)^{* \star *}$ & $0.0194^{\star *}$ & $0.0319^{* * *}$ & $0.0253^{\star * \star}$ & $(0.0021)$ & $0.0224^{* * *}$ & $0.0507^{\star \star \star}$ & 0.0002 & $(0.0122)^{*}$ & $(0.0016)$ \\
\hline SALE/ASSET & $0.1134^{\star * *}$ & $(0.0171)^{* *}$ & $(0.0091)$ & $(0.0572)^{* * \star}$ & $(0.1653)^{* \star \star}$ & $(0.0073)$ & $0.1097^{\star * \star}$ & $(0.0913)^{\star \star \star}$ & $0.0475^{\star * *}$ & $(0.0441)^{\star \star \star *}$ & 0.0074 \\
\hline SPEC & 0.0005 & $(0.0087)$ & $(0.0208)^{\star \star \star}$ & $0.1033^{* * *}$ & 0.0029 & $(0.0115)^{*}$ & $(0.4114)^{\star * *}$ & $0.0948^{* * *}$ & $(0.0346)^{\star * \star}$ & $0.0114^{*}$ & $0.0105^{*}$ \\
\hline
\end{tabular}

\begin{tabular}{|c|c|c|c|c|c|c|c|c|c|c|}
\hline & ECON & GOCN & ICWEAK & INDEP & INV & LEV & LOSS & LSEG & NUMWK & REPORTABLE \\
\hline ECON & 1.0000 & & & & & & & & & \\
\hline GOCN & $(0.0287)^{\star \star \star}$ & 1.0000 & & & & & & & & \\
\hline ICWEAK & $0.1056^{\text {*** }}$ & $0.1019^{* * *}$ & 1.0000 & & & & & & & \\
\hline INDEP & (0.0009) & $(0.0862)^{\star * *}$ & $(0.0611)^{\star * *}$ & 1.0000 & & & & & & \\
\hline INV & $(0.0294)^{\star \star *}$ & $(0.0509)^{\star \star *}$ & $(0.0205)^{* \star *}$ & $0.0205^{\star * *}$ & 1.0000 & & & & & \\
\hline LEV & $(0.0171)^{\star *}$ & 0.1537 *** & $0.0125^{*}$ & $(0.0373)^{\star * \star}$ & $0.0559^{* * *}$ & 1.0000 & & & & \\
\hline LOSS & $(0.0818)^{* * *}$ & $0.2214^{* * *}$ & $0.1288^{* * *}$ & $(0.0658)^{\star \star *}$ & $(0.1330)^{\star \star \star}$ & $0.0527^{* * *}$ & 1.0000 & & & \\
\hline LSEG & $(0.0795)^{\star \star \star *}$ & $(0.0171)^{\star * *}$ & $(0.0243)^{\star \star \star}$ & $0.0132^{*}$ & $0.1027^{* * *}$ & $0.0384^{\star * *}$ & $(0.0292) * \star *$ & 1.0000 & & \\
\hline NUMWK & $0.0843^{* * *}$ & $0.1135^{\star \star *}$ & $0.6830^{\star \star *}$ & $(0.0846)^{\star \star \star *}$ & $(0.0077)$ & $0.0318^{\star \star *}$ & $0.1164^{\star * *}$ & $(0.0093)$ & 1.0000 & \\
\hline REPORTABLE & $0.0470^{* * *}$ & $0.0488^{* * *}$ & $0.2662^{* * *}$ & $(0.0185)^{\star *}$ & $(0.0099)^{*}$ & $(0.0014)$ & $0.0649^{\star * *}$ & $(0.0180)^{* *}$ & $0.2258^{* * *}$ & 1.0000 \\
\hline RES & $0.0158^{* *}$ & $0.0508^{* \star *}$ & $0.1392^{\star \star *}$ & 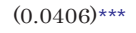 & $(0.0273) * \star \star$ & 0.0028 & $0.0411^{* * *}$ & (0.0069) & $0.1378^{\star \star \star}$ & $0.3472^{\star \star *}$ \\
\hline RESTATE & $0.0779^{* * *}$ & $(0.0086)$ & $0.0736^{* * *}$ & $0.0131^{*}$ & $(0.0257)^{\star \star * *}$ & 0.0094 & 0.0007 & $(0.0238)^{* \star *}$ & $0.0533^{* * *}$ & $0.0293^{* * *}$ \\
\hline RESTRUCT & $(0.0187)^{* *}$ & $0.0148^{*}$ & $0.0251^{* * *}$ & $0.0206^{* * *}$ & $0.1855^{\star * *}$ & $0.0468^{* \star *}$ & $0.1145^{\star \star *}$ & $0.0746^{* * *}$ & $0.0184^{* *}$ & 0.0062 \\
\hline ROA & 0.0063 & $(0.0687)^{\star * *}$ & $(0.0221)^{\star * *}$ & $0.0175^{\star *}$ & $0.0119^{*}$ & $(0.0486)^{\star * \star}$ & $(0.0973) * \star *$ & 0.0051 & $(0.0242) * * *$ & $(0.0080)$ \\
\hline SALE/ASSET & $(0.0023)$ & $(0.0291)^{\star * *}$ & $0.0141^{*}$ & $0.0299^{* * *}$ & $0.2670^{\star \star *}$ & $(0.1112)^{* * *}$ & $(0.0983)^{\star * *}$ & $0.0210^{\star * *}$ & $0.0185^{* *}$ & 0.0085 \\
\hline \multirow[t]{2}{*}{ SPEC } & $0.0104^{*}$ & 0.0057 & $(0.0992)^{\star \star \star}$ & $(0.1258)^{* * *}$ & $(0.0992)^{\star \star *}$ & $0.1538^{* * *}$ & 0.0028 & $(0.0505)^{\star \star *}$ & $0.0121^{*}$ & 0.0020 \\
\hline & & RES & & RESTATE & & RESTRUCT & & ROA & & SALE/ASSET \\
\hline RES & & 1.0000 & & & & & & & & \\
\hline RESTATE & & $0.0147^{*}$ & & 1.0000 & & & & & & \\
\hline RESTRUCT & & $(0.0182)^{\star \star *}$ & & $(0.0050)$ & & 1.0000 & & & & \\
\hline ROA & & (0.0064) & & (0.0061) & & $(0.0178)^{* *}$ & & 1.0000 & & \\
\hline SALE/AT & & $(0.0133)^{*}$ & & 0.0049 & & $0.1415^{* * *}$ & & $0.0787^{\star \star \star}$ & & 1.0000 \\
\hline SPEC & & $0.0400^{* * *}$ & & $(0.0001)$ & & $(0.1163)^{* * *}$ & & $(0.0080)$ & & $(0.2034) * \star \star$ \\
\hline
\end{tabular}

* p b 0.100 .

** p b 0.010 .

$* * * \mathrm{p} \mathrm{b} 0.001$.

when there is a reportable condition (REPORTABLE, $p$ b 0.001), less likely to resign when the audit committee is independent (AINDEP, $p$ b 0.001), and less likely to resign when there is an abnormal fee (ABFEE, $p=$ 0.027) (Ettredge et al., 2007, 2011; Krishnan \& Krishnan, 1997; Lee et al., 2004). Consistent with Krishnan and Krishnan (1997), increased auditor independence (INDEP, $p=0.059$ ) is negatively associated with auditor resignations. ${ }^{13}$

\footnotetext{
${ }^{13}$ We also test for the presence of an industry specific fixed-effect using a two-digit SIC classification. A total of 2879 observations represented by 29 two-digit SIC groups are

dropped due to a lack of variability in the outcome variable (RES). The results based on the remaining 25,389 observations represented by 41 two-digit SIC groups yield conclusions identical to those formally presented.
}

\subsection{Test of hypothesis 2}

To test $\mathrm{H} 2$, we examine the effect of economic outlook on subsequent audit fees when an adverse ICFR report is issued. We predict that risk premiums on audit fees following adverse ICFR opinions will decrease when the economy is weak. Table 6 presents the results for $\mathrm{H} 2$ which is also estimated with a two-way, cluster-robust standard error estimation approach. ${ }^{14}$ Our model is significant ( $p$ b 0.001) with an F-statistic of 2315.56. The regression results presented in Table 6 show a positive ( $p$ b 0.001) coefficient on ICWEAK, which suggests

\footnotetext{
${ }^{14}$ The SAS macro is available at http://acct.wharton.upenn.edu/ dtayl/SAS2 waycluster.
} 
Table 4

Summary of frequency and number of internal control weaknesses.

\begin{tabular}{|c|c|c|c|c|c|}
\hline Year & Obs & $\begin{array}{l}\text { Observations with internal control } \\
\text { weaknesses }(\mathrm{ICWEAK}=1)\end{array}$ & $\begin{array}{l}\text { Percent of observations with internal } \\
\text { control weaknesses (ICWEAK=1) }\end{array}$ & $\begin{array}{l}\text { Total number of internal control } \\
\text { weaknesses (NUMWK) }\end{array}$ & $\begin{array}{l}\text { Average number } \\
\text { of internal control weaknesses for } \\
\text { firms where ICWEAK = } 1\end{array}$ \\
\hline 2004 & 2651 & 472 & 0.18 & 1233 & 2.61 \\
\hline 2005 & 3843 & 519 & 0.14 & 1301 & 2.51 \\
\hline 2006 & 4122 & 417 & 0.10 & 983 & 2.36 \\
\hline 2007 & 4274 & 355 & 0.08 & 792 & 2.23 \\
\hline 2008 & 4497 & 257 & 0.06 & 537 & 2.09 \\
\hline 2009 & 4243 & 185 & 0.04 & 444 & 2.40 \\
\hline 2010 & 4107 & 158 & 0.04 & 320 & 2.02 \\
\hline 2011 & $545^{1}$ & 21 & 0.04 & 45 & 2.14 \\
\hline Total & 28,282 & 2384 & 0.08 & 5655 & 2.37 \\
\hline
\end{tabular}

${ }^{1}$ Our dataset encompasses registrants with an ICFR report from November 15, 2004 to January 5, 2012. The smaller number of observations in 2011 reflects that the vast majority of audit reports for the 2011 year arrived subsequent to January 5, 2012.

that fees assessed by auditors are higher when internal control weaknesses are present. The non-significant coefficient $(p=0.136)$ on ECON suggests that, in general, assessed fees are not adjusted in reference to economic outlook. The positive and significant interaction term $\left(E C O N^{*} I C W E A K, p=0.002\right)$ between adverse ICFR reports and economic outlook indicates that the penalty (i.e., higher fees) is higher for internal control weaknesses when the economy is stronger, therefore indicating that the fee penalty is lower when the economic outlook is less favorable. While the auditor continues to charge a risk premium when an adverse ICFR opinion is issued, they charge a lower risk premium during times of economic difficulty. Thus, we find support for our second hypothesis.

Consistent with prior literature, we find that larger companies (ASSET, $p$ b 0.001; SALE/ASSET, $p=0.072 ;$ AREC, $p=0.003$; INV,

Table 5

Auditor resignations following adverse ICFR opinion in an economic downturn.*

RES $^{1 / 4} \beta_{0} \mathrm{p} \beta_{1} I C W E A K \mathrm{p} \beta_{2} E C O N \mathrm{p} \beta_{3}$ ECON * ICWEAK $\mathrm{p} \beta_{4} A S 5 \mathrm{p} \beta_{5}$ CSIZE $\mathrm{p} \beta_{6}$ BKMK $\mathrm{p} \beta_{7} L E V \mathrm{p} \beta_{8} R O A \mathrm{p} \beta_{9} L O S S \mathrm{p} \beta_{10} S P E C \mathrm{p} \beta_{11} C E O \mathrm{p} \beta_{12}$ GOCN $\mathrm{p} \beta_{13} A B F E E$ $\mathrm{p} \beta_{14}$ BIG $4 \mathrm{p} \beta_{15}$ RESTATE $\mathrm{p} \beta_{16}$ DISAGREE $\mathrm{p} \beta_{17}$ REPORTABLE $\mathrm{p} \beta_{18}$ AINDEP p b 0.001; LSEG, $p$ b 0.001) have higher audit fees (Carcello \& Neal, 2003; Ettredge et al., 2011; Johnson \& Lys, 1990). We also find that more leverage and higher return on assets (LEV, $p$ b 0.000; ROA, $p$ b 0.001) are associated with lower audit fees, while losses (LOSS, $p$ b 0.001) are associated with higher fees (Johnstone \& Bedard, 2004;

Krishnan, 1994). Financial statement restatements, restructuring, and going concern opinions (RESTATE, $p$ b 0.001; RESTRUCT, $p$ b 0.001; GOCN, $p$ b 0.001) are also associated with higher fees (Huang \& Scholz, 2012; Krishnan \& Krishnan, 1997). Lastly, we find that specialist auditors (SPEC, $p$ b 0.001) charge a lower fee (Carcello \& Neal, 2003; Ettredge et al., 2011) but Big 4 auditors (BIG4, $p$ b 0.001) charge a higher fee in general.

\section{Table 6}

Association between internal control weakness and audit fees in economic downturn.*.

InðFEE॰ $1 / 4 \beta_{0} \mathrm{p} \beta_{1}$ ICWEAK $\mathrm{p} \beta_{2} N U M W K \quad \mathrm{p} \beta_{3}$ ECON $\mathrm{p} \beta_{4} E C O N$ * ICWEAK $\mathrm{p} \beta_{5}$ RES $\mathrm{p} \beta_{6} E C O N^{\star} R E S \mathrm{p} \beta_{7} R_{E S}{ }^{\star} I C W E A K \mathrm{p} \beta_{8} E C O N^{\star} I C W E A K^{\star} R E S \mathrm{p} \beta_{9} A S 5$ $\mathrm{p} \beta_{10} A S S E T \mathrm{p} \beta_{11} S A L E=A S S E T \mathrm{p} \beta_{12} L E V \mathrm{p} \beta_{13} R O A \mathrm{p} \beta_{14} L O S S \mathrm{p} \beta_{15} D E L A Y$ $\mathrm{p} \beta_{16}$ AREC $\mathrm{p} \beta_{17} I N V \mathrm{p} \beta_{18}$ SPEC $\mathrm{p} \beta_{19}$ RESTATE $\mathrm{p} \beta_{20}$ LSEG $\mathrm{p} \beta_{21}$ RESTRUCT $\mathrm{p} \beta_{22} G O C N \mathrm{p} \beta_{23} B K M K \mathrm{p} \beta_{24} B I G 4 \mathrm{p} \varepsilon$

\section{$\mathrm{p} \beta_{19} I N D E P \mathrm{p} \beta_{20} A B R E T A N \mathrm{p} \varepsilon:$}

\begin{tabular}{|c|c|c|c|}
\hline Variables & Exp. sign & Coefficient & $\mathrm{p}$-Values \\
\hline Intercept & $+/-$ & $(2.0189)$ & 0.012 \\
\hline ICWEAK & + & 0.8741 & 0.014 \\
\hline ECON & $+/-$ & $(0.1690)$ & 0.000 \\
\hline ECON*ICWEAK & - & 0.3410 & 0.003 \\
\hline AS5 & - & $(0.6616)$ & 0.053 \\
\hline CSIZE & - & $(0.0508)$ & 0.059 \\
\hline BKMK & $+/-$ & 0.0002 & 0.516 \\
\hline LEV & + & 0.0108 & 0.923 \\
\hline ROA & - & $(0.0722)$ & 0.824 \\
\hline LOSS & + & 0.1014 & 0.576 \\
\hline SPEC & $+1-$ & 0.2357 & 0.386 \\
\hline CEO & + & $(0.6844)$ & 0.179 \\
\hline GOCN & + & 0.4969 & 0.135 \\
\hline ABFEE & - & $(0.2293)$ & 0.027 \\
\hline BIG4 & - & $(1.4751)$ & 0.001 \\
\hline RESTATE & + & 0.0649 & 0.780 \\
\hline DISAGREE & + & 0.0761 & 0.937 \\
\hline REPORTABLE & + & 3.8687 & 0.000 \\
\hline AINDEP & - & (1.1859) & 0.000 \\
\hline INDEP & + & $(0.1727)$ & 0.059 \\
\hline ABRETAN & + & 0.2376 & 0.516 \\
\hline Auditor Resignation $=$ & & & 295 \\
\hline Auditor Dismissal $=$ & & & 1149 \\
\hline Nochange $=$ & & & 26,838 \\
\hline Total $\mathrm{n}=$ & & & 28,282 \\
\hline Model Chi-Square $=$ & & & 1007.63 \\
\hline Model Significance $=$ & & & 0.000 \\
\hline Pseudo $R^{2}=$ & & & 0.3073 \\
\hline
\end{tabular}

* We report two-way, cluster-robust standard errors clustered on audit firm and reporting year.

\begin{tabular}{lccc}
\hline Variables & Exp. sign & Coefficient & p-Values \\
\hline Intercept & $+/-$ & 10.3895 & 0.000 \\
ICWEAK & + & 0.2061 & 0.000 \\
NUMWK & + & 0.0902 & 0.000 \\
ECON & + & $(0.0039)$ & 0.136 \\
ECON*ICWEAK & + & 0.0613 & 0.002 \\
RES & + & 0.0370 & 0.683 \\
ECON*RES & + & 0.1152 & 0.028 \\
RES*ICWEAK & $+/-$ & $(0.0614)$ & 0.545 \\
ECON*ICWEAK & $+/-$ & $(0.0381)$ & 0.680 \\
RES & & & \\
AS5 & - & 0.0004 & 0.988 \\
ASSET & + & 0.4409 & 0.000 \\
SALE/ASSET & + & 0.0823 & 0.072 \\
LEV & - & $(0.5097)$ & 0.000 \\
ROA & - & $(0.3499)$ & 0.000 \\
LOSS & + & 0.0913 & 0.000 \\
DELAY & + & 0.0002 & 0.503 \\
AREC & + & 0.0000 & 0.003 \\
INV & + & 0.0000 & 0.000 \\
SPEC & - & $(0.2428)$ & 0.000 \\
RESTATE & + & 0.0962 & 0.000 \\
LSEG & + & 0.1022 & 0.000 \\
RESTRUCT & + & 0.5259 & 0.000 \\
GOCN & + & 0.2042 & 0.000 \\
BKMK & + & $0.1099)$ & 0.000 \\
BIG4 & + & & 0.000 \\
Total $n=$ & & & 28,282 \\
Model F-statistic $=$ & + & & 2315.56 \\
Model Significance & + & & 0.000 \\
R $^{2}=$ & + & & 0.7330 \\
& + & &
\end{tabular}

\footnotetext{
* We report two-way, cluster-robust standard errors clustered on audit firm and reporting year.
} 


\subsection{Researchquestion}

Table 6 also presents the results of a three-way interaction that provides insight into our research question, which examines the impact of the economic outlook on subsequent auditor fees for clients with adverse ICFR opinions who have experienced an auditor resignation $\left(E C O N^{*} I C W E A K^{*} R E S\right)$. The non-significant coefficient on RES ( $p=$ 0.683 ) indicates that resignations in general do not affect subsequent auditor fees. However, the interaction of $E C O N^{*} R E S$ is significant and positive $(p=0.028)$ indicating that a resignation coupled with a strong (weak) economy will result in the subsequent auditor charging higher (lower) incremental fees.

Our results also indicate that, in general, a resignation following an adverse ICFR opinion does not impact subsequent auditor fees, as the coefficient on $R E S^{*} I C W E A K$ is not significant ( $\left.p=0.545\right)$. Further, the three-way interaction of interest in our research question $\left(E C O N^{*} I C W E A K^{*} R E S\right)$ is also not significant $(p=0.680)$, thereby providing no evidence that the economy will impact the fees subsequent auditors charge following a resignation in the presence of an adverse ICFR opinion. Given the higher need for income during a weak economy, those clients who receive adverse ICFR opinions and experience an auditor resignation likely represent the riskiest clients for audit firms. Our lack of significant findings indicates that subsequent auditors are not impacted by the economy when determining how to price the risk associated with such clients. Thus, it appears that for the riskiest of clients, economic factors do not exceed the need for auditors to appropriately price risk.

\section{Summary and discussion}

Our study examines the impact of the economy on auditor risk management strategies, as measured by auditor resignations and fees following adverse ICFR opinions. Our analyses indicate that the economic environment influences both auditor resignations and fee increases following adverse ICFR opinions. We find that when the economy is weak, auditors are less likely to resign from clients with adverse ICFR opinions than when the economy is strong. Further, for those clients with adverse ICFR opinions from whom the auditor does not resign, the fee premium often used to manage risk is lower during times of economic difficulty than otherwise. These results suggest that economic factors influence auditors' propensity to accept and price risk appropriately. However, for the riskiest of clients, clients with adverse ICFR opinions from which auditors resign, we do not find evidence indicating that the successor auditor is influenced by economic factors when making pricing decisions. Our results indicate that, while economic factors impact risk tolerance levels for audit firms overall, they do not influence risk pricing strategies for the most risky clients.

Our findings provide insight into how audit firms manage risk during difficult economic times. Our results indicate that auditors will change their risk management strategies in such a way as to maximize income. In particular, auditors are more willing to remain with risky clients (i.e., firms with adverse ICFR opinions) when the economy is poor. Further, auditors charge a lower risk premium to those clients. Given that increased audit fees are positively associated with dismissals (Ettredge et al., 2007); this may be an effort for firms to avoid losing clients and therefore revenues. However, for the riskiest of clients, successor auditors do not allow economic factors to influence how they price risk. Thus, auditors are willing to change their risk profiles to retain the income provided by risky clients, but only up to a certain point.

Our study extends the risk management literature by examining the impact of adverse ICFR audit opinions on auditors' risk management strategies, both resignations and fee increases, in varying economic environments. Our study also contributes to the growing body of literature that examines the influence of external economic factors on the audit process. Further, our results provide important information to environment, it is especially important that when performing client continuance and acceptance procedures, audit firms carefully consider the need for revenues versus the potential increase in liability resulting from loosened risk management policies.

We note the following area for future research: researchers could continue to investigate the impact of the economic environment on auditor change decisions, relating to both resignations and dismissals, and audit fees. Given that litigation risk remains a concern for firms, an improved understanding of post-SOX resignation and fee patterns could lead to more effective management of engagement risk by audit firms.

\section{Acknowledgments}

We would like to thank Allen Blay and Michael Bamber for helpful suggestions and comments. We also thank participants at the 2013 AAA Audit Midyear Meeting, 2012 AAA Annual Meeting, and 2012 AAA Southeast Regional Meeting for helpful comments on earlier drafts of this paper. Lastly, we would like to thank the Accounting Departments of Appalachian State University and West Virginia University for their financial support.

\section{Appendix A. Variable definitions}

\begin{tabular}{|c|c|}
\hline Variable & Description \\
\hline ABFEE & $\begin{array}{l}\text { Calculated as the residuals from standard audit fee model, }{ }^{\text {a }} \text { based } \\
\text { on findings that abnormal fees are associated with auditor changes } \\
\text { (Ettredge et al., 2007, 2011). }\end{array}$ \\
\hline ABRETAN & $\begin{array}{l}\text { Cumulative abnormal return estimated via the market model for } \\
\text { the client firm over the } 260 \text { trading days prior to the fiscal year end. }\end{array}$ \\
\hline AINDEP & $\begin{array}{l}\text { Audit committee independence, equals } 1 \text { if over half of the audit } \\
\text { committee members are independent and } 0 \text { otherwise, based on } \\
\text { findings that low audit committee independence is more likely to } \\
\text { lead to resignation (Lee et al., 2004). }\end{array}$ \\
\hline AREC & $\begin{array}{l}\text { Level of receivable balances reported as of the close of the reporting } \\
\text { period divided by total assets (Ettredge et al., 2011). We compute } \\
\text { AREC as the natural log of receivables. }\end{array}$ \\
\hline AS5 & $\begin{array}{l}\text { Audit Standard 5. AS5 superseded AS2 as providing guidance for } \\
\text { ICFR audits during our sample period. AS5 equals } 0 \text { in the period } \\
\text { prior to AS5 implementation (2004-2006), } 1 \text { otherwise. }\end{array}$ \\
\hline ASSET & $\begin{array}{l}\text { Total assets based on findings indicating that larger clients are less } \\
\text { likely to experience an auditor change (Carcello \& Neal, 2003; } \\
\text { Ettredge et al., 2011; Johnson \& Lys, 1990). We compute ASSET as } \\
\text { the natural log of total assets. }\end{array}$ \\
\hline BIG4 & $\begin{array}{l}\text { Auditor size, operationalized by classifying auditors as either Big } 4 \\
\text { or non-Big } 4 \text {, where BIG4 equals } 1 \text { if the auditor is a Big } 4 \text {, based on } \\
\text { pre-SOX research that finds that an auditor change is less likely to } \\
\text { occur with a Big } 4 \text { auditor (Johnson \& Lys, 1990) and post-SOX } \\
\text { research that finds that, at least for dismissals, a client is more likely } \\
\text { to dismiss a Big } 4 \text { auditor (Ettredge et al., 2007; Ettredge et al., 2011). }\end{array}$ \\
\hline BKMK & $\begin{array}{l}\text { Book to market calculated as the book value of equity divided by } \\
\text { the market value of equity. Lower values of BKMK indicate higher } \\
\text { growth prospects. Prior research suggests that corporate growth is } \\
\text { associated with auditor realignment (Ettredge et al., 2011; Johnson } \\
\text { \& Lys, 1990). }\end{array}$ \\
\hline CEO & $\begin{array}{l}\text { CEO Change, equals } 1 \text { if the client hired a new CEO during the fiscal } \\
\text { year and } 0 \text { otherwise, based on findings that new CEOs are associated } \\
\text { with auditor changes. }\end{array}$ \\
\hline CSIZE & $\begin{array}{l}\text { Client Size calculated as the natural log of client revenues, based on } \\
\text { findings indicating that larger clients are less likely to experience } \\
\text { and auditor change (Carcello \& Neal, 2003; Ettredge et al., 2011; } \\
\text { Johnson \& Lys, 1990). }\end{array}$ \\
\hline DELAY & $\begin{array}{l}\text { Delay is the number of days between the client's fiscal year end and } \\
\text { audit report date (Ettredge et al., 2011). }\end{array}$ \\
\hline DISAGREE & $\begin{array}{l}\text { Disagreement, equals } 1 \text { if the auditor disclosed information about } \\
\text { disagreements with the client over accounting issues and } 0 \\
\text { otherwise, based on findings of a positive association between } \\
\text { disagreements and resignations (DeFond et al., 1992; Krishnan \& } \\
\text { Krishnan, 1997). }\end{array}$ \\
\hline ECON & $\begin{array}{l}\text { ECON represents the near-term economic environment. We use the } \\
\text { Leading Index for the United States provided by the Federal Reserve }\end{array}$ \\
\hline
\end{tabular}


(continued)

\begin{tabular}{ll}
\hline Variable & Description \\
\hline ECON & $\begin{array}{l}\text { Bank of Philadelphia for the numerical value of our ECON variable. } \\
\text { The Leading Index utilizes multiple economic inputs (e.g., housing } \\
\text { permits, unemployment claims, manufacturing, and interest rates) } \\
\text { to provide one composite index to capture economic trends. }\end{array}$
\end{tabular}

GOCN Going concern, equals 1 if the client received a going concern report and 0 otherwise, based on findings that going-concern reports can lead to auditor change.

INDEP Auditor independence, measured as 1-(fees collected from the client as a percent of the total audit fees collected). INDEP is a proxy for the relative importance of the client in the auditor's portfolio of clients. Auditors are more likely to resign from clients from whom they are more independent financially (Krishnan \& Krishnan, 1997). INV Inventory balances reported as of the close of the reporting period divided by total assets (Ettredge et al., 2011). We compute INV in $\log$ form.

LEV Leverage, calculated as total liabilities divided by total assets, based on findings that companies with increasing leverage are more likely to change auditors (Johnstone \& Bedard, 2004; Krishnan, 1994).

LOSS Loss, equals 1 for clients reporting a loss and 0 otherwise. Prio research finds that less profitable companies are more likely to experience an auditor change (Johnstone \& Bedard, 2004; Krishnan, 1994).

LSEG Log of the number of reporting segments reported by the client (Ettredge et al., 2011).

NUMWK Number of material weaknesses (Ettredge et al., 2007, 2011).

REPORTABLE Reportable event, equals 1 if the auditor disclosed a situation where the client was informed that the auditor questions the accuracy or reliability of the clients disclosed information and 0 otherwise, based on findings that reportable events can lead to resignations due to increased litigation risk (DeFond, 1992; Krishnan \& Krishnan, 1997).

RESTATE Restatement, equals 1 if the client restated their financial statements in a later period and 0 otherwise, based on findings that resignations are more likely to occur following restatements (Huang \& Scholz, 2012; Krishnan \& Krishnan, 1997).

RESTRUCT Takes on the value of 1 if the firm underwent a restructuring during the year, 0 otherwise (Ettredge et al., 2011).

ROA Return on asset, measured as net income divided by total assets. Prior research finds that less profitable companies are more likely to experience an auditor change (Johnstone \& Bedard, 2004; Krishnan, 1994).

SALE/ASSET Total Sales divided by Total Assets based on findings indicating that larger client are less likely to experience an auditor change (Carcello \& Neal, 2003; Ettredge et al., 2011; Johnson \& Lys, 1990).

SPEC Specialist, equals 1 if the predecessor auditor's largest portfolio share is in the client's industry. Portfolio share is based on the sum of fees from each two-digit SIC industry code divided by the auditor's total audit fees (Ettredge et al., 2011). Prior work suggests that clients are less likely to dismiss an industry specialist auditor (Carcello \& Neal, 2003), and more likely to change to an industry specialist (Ettredge et al., 2011).

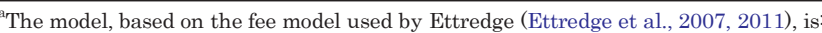

$\ln$ ðFEE $1 \frac{1 / 4}{4} b_{0} \mathrm{p} b_{1}$ LNðASSET $\mathrm{p} b_{2} S A L E=A S S E T \mathrm{p} b_{3}$ LEVERAGE $\mathrm{p} b_{4} R O A \mathrm{p} b_{5} L O S S$ $\mathrm{p} b_{6} B K M K \mathrm{p} b_{7} B I G 4 \mathrm{p} b_{8} D E L A Y \mathrm{p} b_{9} A R E C \mathrm{p} b_{10} I N V E N T O R Y \mathrm{p} b_{11} S P E C I A L I S T$ $\mathrm{p} b_{12} R E S T A T E \mathrm{p} b_{13} L S E G \mathrm{p} b_{14} R E S T R U C T \mathrm{p} b_{15}$ GOCN $\mathrm{p} b_{16} I C W E A K$ p $b_{17} N U M B E R M W \mathrm{p} Y E A R$ :

The model uses all companies receiving internal control reports over our sample period. It is highly significant and variables are significant in directions consistent with prior studies. $\ln (F E E)$ is the natural $\log$ of audit fees; $L N(A S S E T)$ is the natural log of total assets; SALE/ASSET is total client revenue divided by total client assets; DELAY is the number of days between the client's fiscal year-end and audit report date; LSEG is the natural log of the number of operating segments reported by the client; YEAR is an indicator variable for fiscal years. Other variables are defined previously.

\section{References}

American Institute of Certified Public Accountants (AICPA) (2011). A firm's system of quality control (redrafted). Statements on Quality Control Standards, 8, New York, NY: AICPA.

Ashbaugh-Skaife, H., Collins, D. W., \& Kinney, W. R., Jr. (2007). The discovery and reporting of internal control deficiencies prior to SOX-mandated audits. Journal of Accounting and Economics, 44, 166-192.
Bockus, K., \& Gigler, F. (1998). A theory of auditor resignation. Journal of Accounting Research, 36, 191-208.

Canada, J., Sutton, S. G., \& Kuhn, J. R., Jr. (2009). The pervasive nature of IT controls: An examination of material weaknesses in IT controls and audit fees. International

Journal of Accounting and Information Management, 17, 109-119.

Carcello, J. V., \& Neal, T. L. (2003). Audit committee characteristics and auditor dismissals following "New" going-concern reports. The Accounting Review, 78, 95-117.

DeFond, M. (1992). The association between changes in client firm agency costs and

auditor switching. Auditing: A Journal of Practice and Theory, 11, 16-31.

Doyle, J., Ge, W., \& McVay, S. (2007). Determinants of weaknesses in internal control over financial reporting. Journal of Accounting and Economics, 44, 193-223.

Elder, R., Zhang, Y., Zhou, J., \& Zhou, N. (2009). Internal control weaknesses and client risk management. Journal of Accounting, Auditing, and Finance, 24, 543-579.

Ettredge, M., Fuerherm, E. E., \& Li, C. (2014). Fee pressure and audit quality. Accounting Organizations and Society, 39, 247-263.

Ettredge, M., Heintz, J., Li, C., \& Scholz, S. (2011). Auditor realignments accompanying implementation of SOX 404 ICFO reporting requirements. Accounting Horizons, 25, 17-39.

Ettredge, M., Li, C., \& Scholz, S. (2007). Audit fees and auditor dismissals in the SarbanesOxley Era. Accounting Horizons, 21, 371-386.

Gow, I., Ormazabal, G., \& Taylor, D. (2010). Correcting for cross sectional and time series dependence in accounting research. Accounting Review, 85, 483-512.

Hindo, B. (2003, December 1). Audit clients get the heave-ho. BusinessWeek, 7.

Hogan, C., \& Wilkins, M. (2008). Evidence on the audit risk model: Do auditors increase audit fees in the presence of internal control deficiencies? Contemporary Accounting Research, 25, 219-242.

Hoitash, R., Hoitash, U., \& Bedard, J. C. (2008). Internal control quality and audit pricing under the Sarbanes-Act. Auditing: A Journal of Practice and Theory, 27, 105-126.

Huang, Y., \& Scholz, S. (2012). Evidence on the association between financial restatements and auditor resignations. Accounting Horizons, 26, 439-464.

International Auditing and Assurance Standards Board (2009). Audit considerations in respect of going concern in the current economic environment. New York, NY: International Federation of Accountants.

Johnson, W. B., \& Lys, T. (1990). The market for audit services: Evidence from voluntary auditor changes. Journal of Accounting and Economics, 12, 281-308.

Johnstone, K., \& Bedard, J. (2004). Audit firm portfolio management decisions. Journal of Accounting Research, 42, 659-690.

Krishnan, J. (1994). Auditor switching and conservatism. The Accounting Review, 69, 200-215.

Krishnan, J., \& Krishnan, J. (1997). Litigation risk and auditor resignations. The Accounting Review, 72, 539-560.

Krishnan, G. V., \& Visvanathan, G. (2007). Reporting internal control deficiencies in the post-Sarbanes-Oxley era: The role of auditors and corporate governance. International Journal of Auditing, 11, 73-90.

Krishnan, G. V., \& Zhang, Y. (2014). Is there a relation between audit fee cuts during the global financial crisis and banks' financial reporting quality? Journal of Accounting \& Public Policy, 33, 279-300.

Landsman, W., Nelson, K., \& Rountree, B. (2009). Auditor switches in the pre- and postEnron eras: Risk or realignment? The Accounting Review, 84, 531-558.

Lee, H., Mande, V., \& Ortman, R. (2004). The effect of audit committee and board of director independence on auditor resignation. Auditing: A Journal or Practice and Theory, 23, 131-146.

Leone, A., Rice, S., Weber, J., \& Willenborg, M. (2013). How do auditors behave during periods of marke euphoria? The case of internet IPOs. Contemporary Accounting Research, 30, 182-214.

Munsif, V., Raghunandan, K., Rama, D. V., \& Singhvi, M. (2011). Audit fees after remediation of internal control weaknesses. Accounting Horizons, 25, 87-105.

Pratt, J., \& Stice, J. (1994). The effects of client characteristics on auditor litigation risk judgments, required audit evidence, and recommended audit fees. The Accounting Review, 69, 639-656.

Public Company Accounting Oversight Board (PCAOB) (2003). System of quality control for a CPA firm's accounting and auditing practice. Quality Control Section 20. Washington, D.C.: PCAOB.

Public Company Accounting Oversight Board (PCAOB) (2008). Audit considerations in the current economic environment. Staff Audit Practice Alert No. 3. Washington, D.C.: PCAOB.

Raghunandan, K., \& Rama, D. V. (2006). SOX Section 404 material weakness disclosures and audit fees. Auditing: A Journal of Practice and Theory, 25, 99-114.

Ramos, M. (2009, October 19). Ride the bear: Strategies for CPA firms to survive, thrive, and grow in a down economy. Available at: http://www.aicpa.org/interestareas/ privatecompaniespracticesection/resources/marketingandpracticegrowth/pages/ ride $\% 20$ the $\% 20$ bear-strategies $\% 20$ for $\% 20$ cpa $\% 20$ firms $\% 20$ to $\% 20$ survive $\% 20$ thrive $\%$ 20and\%20grow\%20in\%20a\%20down\%20economy.aspx

Schroeder, J., \& Hogan, C. (2013). The impact of PCAOB AS5 and the economic recession on client portfolio characteristics of the big 4 audit firms. Auditing: A Journal of Practice and Theory, 32, 95-127.

Shu, S. (2000). Auditor resignations: Clientele effects and legal liability. Journal of Accounting and Economics, 29,173-205.

Thevenot, M., \& Hall, L. (2011). Adverse internal control over financial reporting opinions and auditor dismissals/resignations. Academy of Accounting and Financial Studies Journal, 15, 41-60.

Turner, L., Williams, J., \& Weirich, T. (2005). An inside look at auditor changes. CPA Journal, $12-21$ (Nov., (Special Auditing Issue)).

U.S. House of Representatives (2002). The Sarbanes-Oxley Act of 2002. Public Law. (pp. 107-204)Washington, D.C.: Government Printing Office (H.R. 3763). 